\title{
Harmful Algal in Banyuasin Coastal Waters, South Sumatera
}

\author{
${ }^{\square}$ Riris Aryawati $^{1,4}$, Dietriech Geoffrey Bengen ${ }^{2}$, Tri Prartono ${ }^{2}$, Hilda Zulkifli ${ }^{3}$
}

DOI: http://dx.doi.org/10.15294/biosaintifika.v8i2.6356

${ }^{1}$ Marine Sciences Department, Faculty of Mathematics and Natural Sciences, Sriwijaya University, Palembang, Indonesia

${ }^{2}$ Marine Sciences Department, Faculty of Fisheries and Marine Sciences, Bogor Agricultural University, Bogor, Indonesia

${ }^{3}$ Biology Department, Faculty of Mathematics and Natural Sciences, Sriwijaya University, Palembang, Indonesia

${ }^{4}$ School of Post Graduate Studies, Bogor Agricultural University, Bogor, Indonesia

\section{History Article}

Received 17 June 2016

Approved 28 August 2016

Published 18 September 2016

\section{Keywords:}

harmful algae; temporal; Banyuasin water South Sumatera

\begin{abstract}
Phytoplankton have important as food-chain major component and primary production of marine environment. However, high abundance of phytoplankton could give harmful effects toward water ecosystem. Moreover, they could produce toxic substances that will be accumulated within their consumer. This accumulation could be dangerous for human or animals. This research were aimed to determine and calculatespecies of harmful algae in Banyuasin coastal waters. The study was conducted on April, June, August, October and December of 2013, and in February 2014 , at ten stations. Phytoplankton samples were taken vertically using plankton nets. In the form of cone-shaped with a diameter of $30 \mathrm{~cm}$, length $100 \mathrm{~cm}$ and mesh size $30 \mu \mathrm{m}$. The result showed that there are 35 genera of phytoplankton. That have been found and consisted of four groups; Bacillariophyceae, Dinophyceae, Cyanophyceae and Chlorophyceae. 13 species were identified as Harmful Algal (Chaetoceros, Coscinodiscus, Nitzschia, Skeletonema, Thalassiosira, Alexandrium, Ceratium, Dinophysis, Noctiluca, Protoperidinium, Prorocentrum, Anabaena dan Oscillatoria), with seven of them were known for having toxin (Nitzschia, Alexandrium, Dinophysis, Protoperidinium Prorocentrum, Anabaena and Oscillatoria). Monitoring result showed that the highest number of species of potential harmful algal blooms (HABs) occured in June and the highest abundance occured in August, especially Chaetoceros and Skeletonema.
\end{abstract}

\section{How to Cite}

Aryawati, R., Bengen, D. G., Prartono, T., \& Zulkifli, H. (2016). Harmful Algal in Banyuasin Coastal Waters, South Sumatera. Biosaintifika: Journal of Biology \& Biology Education, 8(2), 231-239.

(C) 2016 Semarang State University

Correspondence Author:

p-ISSN 2085-191X

J1. Raya Palembang-Prabumulih Km.32 Indralaya, Sumatera Selatan 30662 Indonesia e-ISSN 2338-7610 


\section{INTRODUCTION}

Phytoplankton serve as primary producer of aquatic food web, and hence become crucial organism for all aquatic life. In other side, some phytoplankton species can produce toxins that harm to organisms, such as animals and humans (Anderson et al., 2002; Anderson et al., 2010). In addition, the excessive alga population may result in severe aquatic environment. For instance, the death of algae which sink to the water's bottom will stimulate the growth of decomposer bacterium that exhaust dissolved oxygen concentration and lead to anoxic condition. This condition may kill many fish and cause the disruption of food web due to the replacement of some organism with other organisms, specially the ones with better endurance.

Algal bloom is a rapid increase in the population of algae in water system. Pednekar (2012) stated that during algal bloom, the phytoplankton density reached $10^{6} \mathrm{cells} . \mathrm{m}^{-3}$ for small sized phytoplankton. Harmful Algal Blooms (HABs) could be defined as overgrowths of algae that usually produce dangerous toxins in fresh or marine water.

Hallegraeff (1995) classified HABs into three groups. The first group is characterized by their ability to change the water column, then reduce the dissolved oxygen and thus harmful for aquatic organisms, i.e: dinoflagellata Gonyaulax polygramma, Noctiluca scintillans, Scrippsiella trochoidea, cyanobacterium Trichodesmium erytrhrae$u m$.The second group is algae that produce toxin and harmful for human, i.e: dinoflagellata Alexandrium acatenella, A. Tamarense, Gymnodinium catenatum, Pyrodinium bahamense, Dinophysis acuta, $D$. acuminata, $D$. rotundata, Prorocentru lima, diatom Pseudo-nitzschia multiseries, P. Australis, cyanobacteria Anabaena circinalis, Nodularia spumigena. The third group is algae that do not harmful for human but endanger for marine organism due to impair and clog the marine organism respiratory system (gills fishes), i.e: diatom Chaetoceros convolutus and dinoflagellata Gymnodinium mikimotoi. Those species were commonly found in tropical area, including Indonesia (Praseno \& Sungestiningsih, 2000).

It is unclear what kind of condition can cause HABs. It could be the impact of over load nutrient or climate change toward the algae growth (Anderson et al.,2002; Sellner et al., 2003; and Pednekar et al., 2012). (Anderson et al., 2002). Furthermore, some scientist point out that the occurences of HABs species were related to climate condition that affect aquatic environ- ment such as salinity, temperature, current, nutrient, seasonal pattern and geomorphology condition. (Tan et al., 2006 and Tilstone et al., 1994 in Pednekar et al., 2012). Makmur (2008) expressed that HABs are resulted from coastal upwellingand possibly supported by high nutrient input, suitable temperature, oxygen availability, and suitable light intensity.In addition, HABs can be activated by the decrease of predator of herbivore (Danielsdottir et al., 2007).

Banyuasin water as the river mouth of two big river in South Sumatera (Musi River and Banyuasin River) has potential condition to stimulate HABs disaster. Previous studies has found some HABs species in the coast of South Sumatera like Ceratium, Pseudonitzschia, Skeletonema with total density of each was $0,5.10^{3}$ cells. $\mathrm{m}^{-3}$, $1.10^{3}$ cells. $\mathrm{m}^{-3}$, and $1.323 .10^{6} \mathrm{cells} . \mathrm{m}^{-3}$ respectively, whereas nutrien concentration was $0.015-0.145$ $\mathrm{mg} . \mathrm{L}^{-1}$ for nitrate and $0.003-0.054 \mathrm{mg} . \mathrm{L}^{-1}$ for phosphate (Aryawati et al., 2005). In 2011, Surbakti et al., also found two potential HABs diatom (Pseudonitzschia and Skeletonema) and four toxic dinoflagellata (Ceratium, Dinophysis, Gymnodinium and Pyrodinium) with nitrate, phosphate, and ammonia concentration were $2.8 \mathrm{mg} . \mathrm{L}^{-1}$; $0.01-2.25 \mathrm{mg} . \mathrm{L}^{-1}$, and $0-0.05 \mathrm{mg} . \mathrm{L}^{-1}$, respectively.

Those previous studies indicated tendency of HABs increasing number and density. This phenomena probably could be related with increasing of nutrient concentration. Prianto (2010) reported the high nutrient concentration in Musi River up to $8 \mathrm{mg} . \mathrm{L}^{-1}, 0.05-1.54 \mathrm{mg} . \mathrm{L}^{-1}$, and $0,1-, 26 \mathrm{mg} . \mathrm{L}^{-1}$ for nitrate, nitriteand ammonia, respectively. The similar high nutrient consentration in South Sumatera Coastal was also found by Isnaini (2014a), i.e. 1,0-2,1 mg. $\mathrm{L}^{-1}$ , 0.22-0.31 mg. $\mathrm{L}^{-1}$ and $0.03-0.07 \mathrm{mg} . \mathrm{L}^{-1}$ for nitrate, phosphate and ammonia, respectively.

Due to previous study that was done on July-August, our research will extend more detail information about possibility of HABs in Banyuasin Water of South Sumatera. It is important to investigatethe current condition of Banyuasin Water that is potential to induce HABs, so that we can reduce their harmful effects.

\section{METHODS}

\section{Sampling Area}

The sampling was carried out in Banyuasin water, South Sumatera on April, June, August, October, December 2013, and February 2014, which will be then mentioned as a series of $1^{\text {st }}$ month to $6^{\text {th }}$ month. Ten sampling stations 
were arranged in the river mouth by using purposive random sampling, distributed from river side to the sea side (Figure 1).

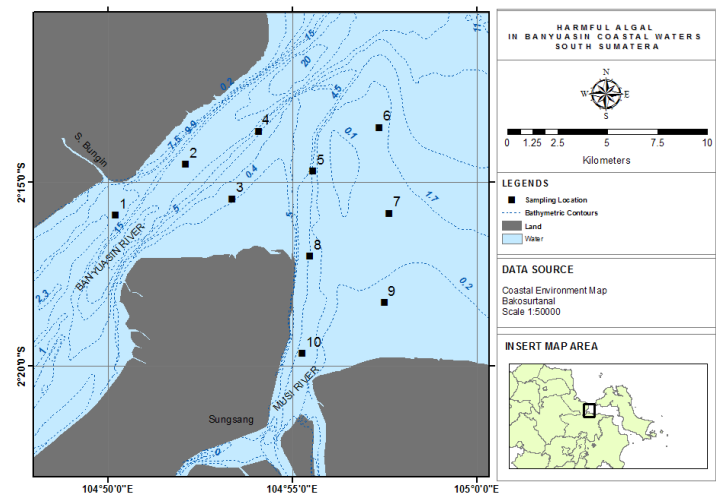

Figure 1. Location of research stations in Banyuasin Water

\section{Data Collection}

Sample of phytoplankton, referring to Aquino et al. (2010) and Mulyani et al. (2012) was collected vertically within $2 \mathrm{~m}$ depth of water surface by using plankton net with a diameter of $30 \mathrm{~cm}$, long of $100 \mathrm{~cm}$, and mesh size of $30 \mu \mathrm{m}$ Phytoplankton samples were kept in the sample bottle $(250 \mathrm{ml})$ and preserved with $4 \%$ formaldehyde (Edler \& Elbrachter, 2010).

Phytoplankton was observed by using microscope equiped by Sedgwick Rafter Counting Cell (SRCC). Phytoplankton was identified by referring several manual books of plankton identification (Yamaji, 1966; Tomas, 1997). The phytoplankton abundance was calculated based on APHA formula (APHA, 1992).

\section{Physicochemical Properties of the Environ- ment}

In addition, the water parameters such as temperature, salinity, and turbidity were measured in situ by CTD (Conductivity Temperature Depth). Water sample for nitrate and phosphate analysis was collected by water sampler, poured into the $250 \mathrm{ml}$ bottle sample and kept in a coolbox. Measurement of nitrate and phosphate concentration was done by referring SNI procedures (2004) by using spectrophotometry.

\section{Data Analysis}

Data of phytoplankton and water parameters was analyzed using MS Excel in Table or Graph forms.

\section{RESULTS AND DISCUSSION}

\section{Phtoplankton Species}

A number of 35 phytoplankton genera were identified in Banyuasin water which can be categorized into four groups, i.e: Bacillariophyceae (26 genera), Dinophyceae (6 genera), Cyanophyceae (2 genera) dan Chlorophyceae (1 genus) (Table 1). Some species such as Bacteriastrum, Chaetoceros, Coscinodiscus, Nitzschia,Rhizosolenia, Skeletonema, Thalassiosira, Thalassiothrix and Protoperidinium were found frequently. These species are common phytoplankton species in South Sumatera coast (Aryawati et al., 2005; Isnaini et al., 2012), also in Indonesia water and other territorial regions (Haumahu, 2004; Fathi \& A1Kahtani, 2009; Rokhim, et al., 2009; Ismunarti, 2013; Thoha \& Aryawati, 2014).

Chaetoceros was found every month probably due to their high adaptation level. Morphologycally, Chaetoceros has many setae, and large size. It commonly lives in colonies. Furthermore, Skeletonema and Thalassiosira also have high adaptation to environmental condition that might be supported by living in colony and long-chain cells. Thoha (2003) also found dominant diatom of Chaetoceros, Thalassionema and Thalassiothrix in Riau islands water, and dominant dinophyceae of Ceratium. The phytoplankton abundance of Banyuasin water was represented in Table 2.

Table 2 showed that Bacillariophyceae have the highest number of genera. This result is similar to some previous studies by Aryawati et al. (2005); Surbakti et al. (2011); Isnaini et al. (2012); Isnaini et al. (2014a); and Isnaini et al. (2014b). Tomas (1997) point out that Bacillariophyceae could distribute widely, live in different habitat and tend to become dominant algae in an open sea, coastal, and estuarine area. Bacillariophyceae domination was probably due to its higher reproduction rate than Dinophyceae or other phytoplankton groups. Lagus et al. (2004) reported that diatoms (Chaetoceros wighamii and Skeletonema costatum) have a very quick response to the addition of nutrients, thus become dominant groups. Diatom could reproduce three times in 24 hours as nutrient increase, but only once in 24 hours for Dinophyceae (Praseno \& Sugestiningsih, 2000).

\section{The Possible Occurence of HABs}

As being described in the pevious pharagraphs, several phytoplankton categorized as 
Riris Aryawati et al. / Biosaintifika 8 (2) (2016) 231-239

Table 1. Identified phytoplankton in Banyuasin water

\begin{tabular}{|c|c|c|c|c|c|c|c|}
\hline \multirow{2}{*}{ No } & \multirow{2}{*}{ Phytoplankton } & \multicolumn{6}{|c|}{ Months } \\
\hline & & $1^{\text {st }}$ & $2^{\text {nd }}$ & $3^{\mathrm{rd}}$ & $4^{\text {th }}$ & $5^{\text {th }}$ & $6^{\text {th }}$ \\
\hline & \multicolumn{7}{|l|}{ Bacillariophyceae } \\
\hline 1 & Amphora & + & - & - & + & - & + \\
\hline 2 & Asterionella & - & - & - & - & + & - \\
\hline 3 & Bacillaria & - & - & - & - & + & + \\
\hline 4 & Bacteriastrum & + & + & + & + & + & + \\
\hline 5 & Chaetoceros & + & + & + & + & + & + \\
\hline 6 & Coscinodiscus & + & + & + & + & + & + \\
\hline 7 & Dictyliosolen & + & - & + & - & - & - \\
\hline 8 & Dictyocha & - & - & + & + & - & - \\
\hline 9 & Dytilum & - & + & + & + & + & + \\
\hline 10 & Eucampia & - & - & + & - & - & - \\
\hline 11 & Guinardia & - & + & + & + & + & + \\
\hline 12 & Hemidiscus & - & + & + & + & + & - \\
\hline 13 & Hemiaulus & + & - & + & + & + & + \\
\hline 14 & Lauderia & - & + & + & + & - & + \\
\hline 15 & Leptocylindrus & + & + & + & - & - & + \\
\hline 16 & Mellosira & - & - & - & + & + & - \\
\hline 17 & Nitzschia & + & + & + & + & + & + \\
\hline 18 & Odontela & - & + & + & + & + & + \\
\hline 19 & Pleurosigma & - & - & + & + & - & + \\
\hline 20 & Podocystis & - & - & - & + & - & - \\
\hline 21 & Rhizosolenia & + & + & + & + & + & + \\
\hline 22 & Skeletonema & + & + & + & + & + & + \\
\hline 23 & Surirella & + & + & - & - & + & + \\
\hline 24 & Syendra & - & - & - & - & - & + \\
\hline 25 & Thalassiosira & + & + & + & + & + & + \\
\hline \multirow[t]{2}{*}{26} & Thalassiothrix & + & + & + & + & + & + \\
\hline & \multicolumn{7}{|l|}{ Dinophyceae } \\
\hline 27 & Alexandrium & - & - & + & + & - & - \\
\hline 28 & Ceratium & - & + & - & - & + & + \\
\hline 29 & Dinophysis & - & + & + & - & - & + \\
\hline 30 & Noctiluca & + & - & - & - & + & - \\
\hline 31 & Prorocentrum & + & - & - & - & + & - \\
\hline \multirow[t]{2}{*}{32} & Protoperidinium & + & + & + & + & + & + \\
\hline & \multicolumn{7}{|l|}{ Cyanophyceae } \\
\hline 33 & Anabaena & - & + & + & - & - & - \\
\hline \multirow[t]{2}{*}{34} & Oscillatoria & - & + & - & - & - & + \\
\hline & \multicolumn{7}{|l|}{ Chlorophyceae } \\
\hline 35 & Staurastrum & - & - & - & - & + & - \\
\hline \multicolumn{2}{|c|}{ number of genera } & 16 & 20 & 24 & 21 & 22 & 23 \\
\hline
\end{tabular}

Note : + : found; - : not found 
Riris Aryawati et al. / Biosaintifika 8 (2) (2016) 231-239

Table 2. The phytoplankton abundance $\left(\mathrm{cells}^{-3} \mathrm{~m}^{-3}\right)$ from Banyuasin water

\begin{tabular}{|c|c|c|c|c|c|c|c|}
\hline \multirow[t]{2}{*}{ No } & \multirow[t]{2}{*}{ Phytoplankton } & \multicolumn{6}{|c|}{ Abundance (cells.m ${ }^{-3}$ ) } \\
\hline & & $1^{\text {st }}$ & $2^{\text {nd }}$ & $3^{\text {rd }}$ & $4^{\text {th }}$ & $5^{\text {th }}$ & $6^{\text {th }}$ \\
\hline & \multicolumn{7}{|l|}{ Bacillariophyceae } \\
\hline 1 & Amphora & 708 & 0 & 0 & 1.345 & 0 & 4.247 \\
\hline 2 & Asterionella & 0 & 0 & 0 & 0 & 21.234 & 0 \\
\hline 3 & Bacillaria & 0 & 0 & 0 & 0 & 5.662 & 37.511 \\
\hline 4 & Bacteriastrum & 9.910 & 2.831 & 104.388 & 21.165 & 12.740 & 21.232 \\
\hline 5 & Chaetoceros & 42.824 & 30.434 & 15.582 .485 & 12.742 & 96.970 & 60.158 \\
\hline 6 & Coscinodiscus & 2.831 & 25.480 & 144.021 & 70.219 & 21.234 & 51.666 \\
\hline 7 & Dictyliosolen & 29.019 & 0 & 1.415 & 0 & 0 & 0 \\
\hline 8 & Dictyocha & 0 & 0 & 1.415 & 1.416 & 0 & 0 \\
\hline 9 & Dytilum & 0 & 32.558 & 56.971 & 1.274 & 2.123 & 8.493 \\
\hline 10 & Eucampia & 0 & 0 & 18.047 & 0 & 0 & 0 \\
\hline 11 & Guinardia & 0 & 2.831 & 12.385 & 1.699 & 1.416 & 1.416 \\
\hline 12 & Hemidiscus & 0 & 1.416 & 1.415 & 425 & 1.416 & 0 \\
\hline 13 & Hemiaulus & 709 & 0 & 147.913 & 1.274 & 1.416 & 2.831 \\
\hline 14 & Lauderia & 0 & 33.265 & 171.622 & 2.548 & 0 & 2.123 \\
\hline 15 & Leptocylindrus & 2.831 & 7.786 & 4.246 & 0 & 0 & 6.370 \\
\hline 16 & Mellosira & 0 & 0 & 0 & 425 & 21.943 & 0 \\
\hline 17 & Nitzschia & 21.587 & 44.805 & 164.545 & 12.883 & 40.345 & 67.236 \\
\hline 18 & Odontela & 0 & 10.617 & 67.941 & 4.247 & 2.123 & 18.402 \\
\hline 19 & Pleurosigma & 0 & 0 & 1.415 & 4.247 & 0 & 708 \\
\hline 20 & Podocystis & 0 & 0 & 0 & 425 & 0 & 0 \\
\hline 21 & Rhizosolenia & 2.831 & 4.247 & 115.005 & 3.044 & 1.416 & 21.233 \\
\hline 22 & Skeletonema & 1.776 .438 & 563.331 & 8.686 .175 & 96.694 & 377.259 & 627.769 \\
\hline 23 & Surirella & 708 & 708 & 0 & 0 & 1.416 & 6.370 \\
\hline 24 & Syendra & 0 & 0 & 0 & 0 & 0 & 708 \\
\hline 25 & Thalassiosira & 35.036 & 115.153 & 409.416 & 216.108 & 69.367 & 323.444 \\
\hline \multirow[t]{2}{*}{26} & Thalassiothrix & 23.357 & 48.837 & 1.012 .039 & 11.609 & 18.402 & 352.464 \\
\hline & Dinophyceae & & & & & & \\
\hline 27 & Alexandrium & 0 & 0 & 2.831 & 2.831 & 0 & 0 \\
\hline 28 & Ceratium & 0 & 1.416 & 0 & 0 & 12.033 & 10.616 \\
\hline 29 & Dinophysis & 0 & 5.416 & 2.123 & 0 & 0 & 708 \\
\hline 30 & Noctiluca & 708 & 0 & 0 & 0 & 21.235 & 0 \\
\hline 31 & Prorocentrum & 2.832 & 0 & 0 & 0 & 1.416 & 0 \\
\hline \multirow[t]{2}{*}{32} & Protoperidinium & 5.662 & 10.617 & 16.631 & 3.822 & 4.954 & 2.831 \\
\hline & Cyanophyceae & & & & & & \\
\hline 33 & Anabaena & 0 & 33.973 & 74.310 & 0 & 0 & 0 \\
\hline \multirow[t]{2}{*}{34} & Oscillatoria & 0 & 14.868 & 0 & 0 & 0 & 372.272 \\
\hline & Chlorophyceae & & & & & & \\
\hline 35 & Staurastrum & 0 & 0 & 0 & 0 & 708 & 0 \\
\hline
\end{tabular}

Note: genera name with underline mark represent the HABs genera 

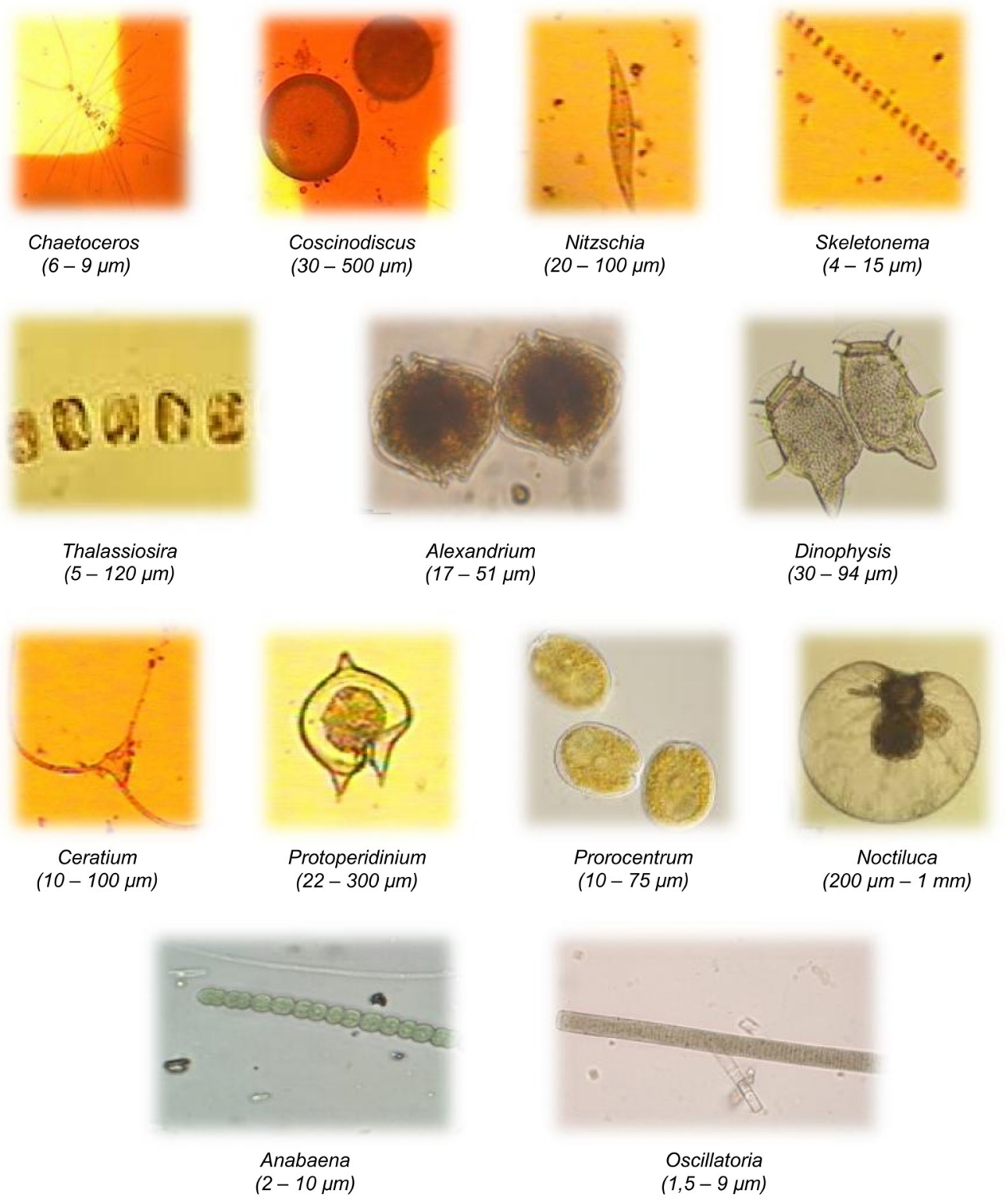

Figure 2. Identified harmful algal that was found in Banyuasin water

HABs. Chaetoceros, Coscinodiscus, Skeletonema, Thalassiosira, Ceratium dan Noctiluca are categorized as intoxic harmfull algae. However, their abundance might cause serious effect to the aquatic ecosystem such as reduction of dissolved oxygen concentration, and clogginess of the fish gill through the formation of sharp cell chain. In contrast, Nitszchia, Alexandrium, Dinophysis, Protoperidinium Prorocentrum, Anabaena and Oscillatoria are algae with toxic that could harm the human health (Figure 2).

Monitoring result showed that the highest number of potential HABs was occured in June and the highest abundance occured in August, especially Chaetoceros and Skeletonema (Figure 3).
Both genera are commonly observed in Banyuasin (Aryawati et al., 2005; Isnaini et al., 2012; Surbakti et al., 2011).Sidabutar (2006) showed that in November 2004, blooming of Skeletonema and Noctiluca has been reported in Jakarta Bay, and recently, algae bloom has been reported especially in Ancol Beach where Coscinodiscus spp has been identified (P2O-LIPI, 2015). Both occasion have caused the massive death of fishes. The indication of Coscinodiscus bloom in Ancol Beach, its abundance had reached 29.000 sel.L-1 during August 2012 (Siagian, 2006; Yuliana, 2012). However, in Hurun Bay, the bloom of Skeletonema has occured with the number of cell was than $180.10^{6}$ cells.m ${ }^{-3}$ in August. Abundance 


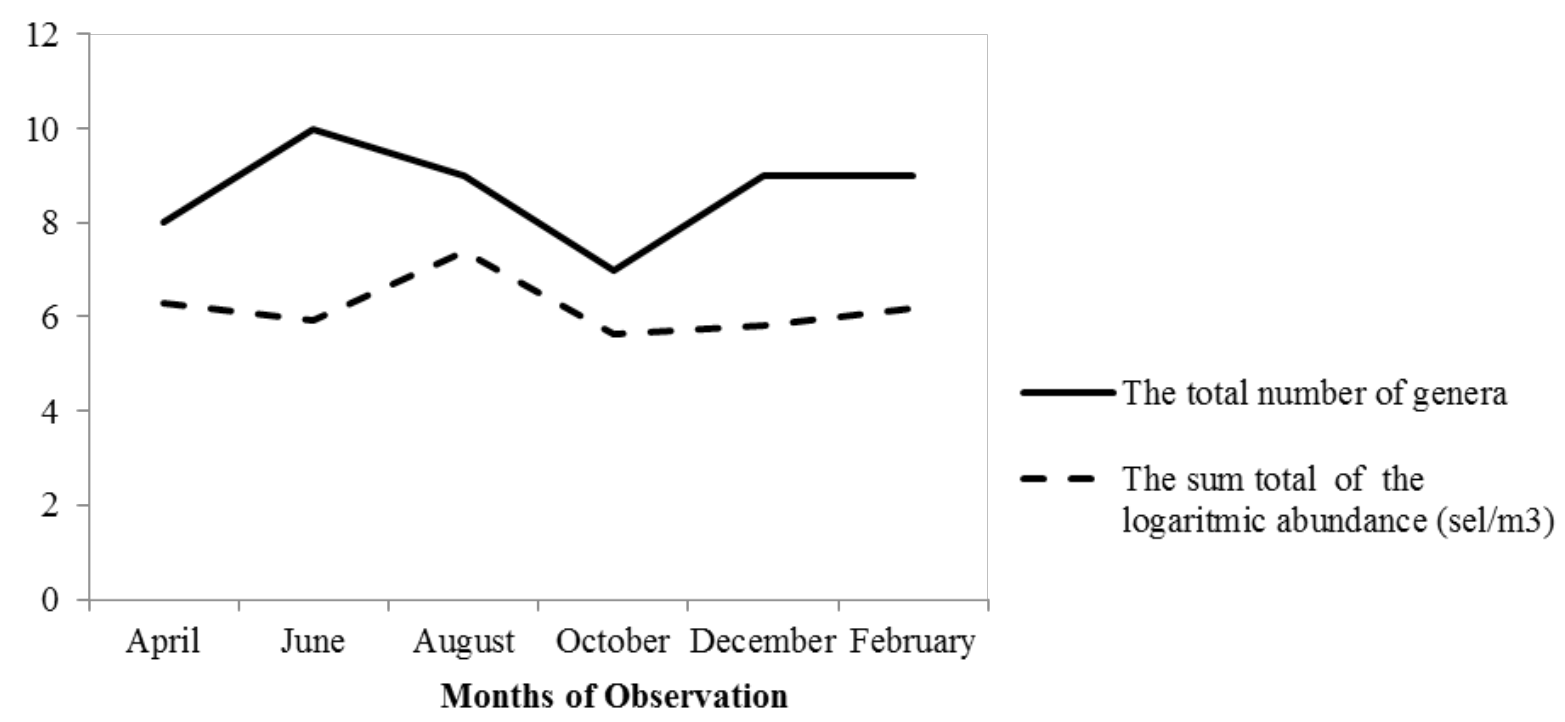

Figure 3. Number of genera and abundance of potential HABs phytoplankton

Table 3. Chemical physics properties of Banyuasin water

\begin{tabular}{lcccccc}
\hline Parameters & $1^{\text {st }}$ & $2^{\text {nd }}$ & $3^{\text {rd }}$ & $4^{\text {th }}$ & $5^{\text {th }}$ & $6^{\text {th }}$ \\
\hline Temperature $\left({ }^{0} \mathrm{C}\right)$ & 30.05 & 29.86 & 28.41 & 29.30 & 28.34 & 28.75 \\
Salinity (PSU) & 13.25 & 24.94 & 24.55 & 23.62 & 17.06 & 25.10 \\
Turbidity (NTU) & 20.31 & 26.13 & 36.61 & 24.24 & 32.22 & 32.16 \\
Nitrate (mg. - $\left.^{-1}\right)$ & 1.46 & 1.13 & 2.18 & 1.92 & 1.87 & 1.37 \\
Phosphate $\left(m g . L^{-1}\right)$ & 0.52 & 0.69 & 0.56 & 0.54 & 0.57 & 0.38 \\
\hline
\end{tabular}

of Skeletonema in the either month was indicated as the number less than $20.10^{6}$ cells.m. ${ }^{-3}$ (Widiarti, 2000)

Algae blooming has occured many times at Ambon Bay on certain months. Sidabutar (2006) stated that some bloomings were happened in different algae species, abundance and time, i.e: Trichodesmium erythraeum (Oscillatoria) with abundance of $3,0.10^{7}$ cells. $\mathrm{m}^{-3}$ on July 1996 , Noctiluca $\left(3.10^{8}\right.$ cells. $^{-3}$, on August 1996), and Alexandrium ( $2,0.10^{9}$ cells.m ${ }^{-3}$, on October 1997). Research of Sidabutar (1997) indicated that Noctiluca population started increase on July and gain the peak on November. Research by Haumahu (2004) atinner side of Ambon bayon May-July 1994 did not find any Noctiluca in water column. Similar research by Haumahu (2005) on Haria Saparua bay,Central Maluku on August-October 2002 also did not find Noctiluca.

\section{Environmental Physicochemical Properties}

Chemical physics properties of Banyuasin water indicate appropriate conditions for the growth of phytoplankton (Table 3).

In comparation with other regions in Indo- nesia (Table 4), there are similarities characters among Banyuasin and other waters.

Table 4 informed that nitrateand phosphate content in South Sumatera waters tend to increase year to year. This condition potentially cause eutrophicin the future and furthermore can trigger algae blooming of certain species. Pednekar et al. (2012) stated that the abundance of HABs species in coastal waters related to increasing of nutrient content from estuarine as effect of anthropogenic activity. Previous study by Hasani, et al. (2012) also indicated positive significance correlation between nitrateand phosphate content with HABs in some aquaculture area in Lampung Bay. However, based on algae blooming phenomenon which previously occured in Indonesia, and supported by appropriate environmental condition (Table 3).

According to Muawanah et al. (2013), the blooming pattern of Cochlodinium polykrikoides at Hurun Bay, Lampung was having characteristic of DIN concentration increased at the beginning which was then followed by a rapid decreased of it due to the consumption by C. polykrikoides characterized by increasing of DIN concen- 
Riris Aryawati et al. / Biosaintifika 8 (2) (2016) 231-239

Table 4. Chemical physics parameters of some Indonesia waters

\begin{tabular}{|c|c|c|c|c|c|}
\hline \multicolumn{4}{|c|}{ Parameters } & \multirow[b]{2}{*}{ Location } & \multirow[b]{2}{*}{ Source } \\
\hline $\begin{array}{l}\text { Tempera- } \\
\text { ture }\left({ }^{0} \mathrm{C}\right)\end{array}$ & $\begin{array}{l}\text { Salinity } \\
\text { (PSU) }\end{array}$ & $\begin{array}{l}\text { Nitrate } \\
\left(\mathrm{mg} \cdot \mathrm{L}^{-1}\right)\end{array}$ & $\begin{array}{l}\text { Phosphat } \\
\left(\mathrm{mg} . \mathrm{L}^{-1}\right)\end{array}$ & & \\
\hline $25.57-30.7$ & $30-34.1$ & $0.0002-0.0046$ & $0.0003-0.0011$ & Ambon Bay & Sidabutar (1997) \\
\hline $24.8-31$ & $26-34$ & $0.05-1.60$ & $0.01-1.50$ & Hurun Bay & Widiarti (2000) \\
\hline $25.27-28.30$ & $31.74-34.42$ & $0.44-4.29$ & $0.30-1.22$ & Ambon Bay & Haumahu (2004) \\
\hline $26.5-30.1$ & $25.5-31.10$ & $0.015-0.145$ & $0.003-0.054$ & South Sumatera waters & Aryawati, et al. (2005) \\
\hline $29-33$ & $5-20$ & $0.608-1.487$ & $0.01-0.06$ & South Sumatera waters & Isnaini, et al. (2012) \\
\hline $30-32$ & $20-27$ & $0.64-2.62$ & $0.13-1.81$ & Jakarta Bay & Mulyani, et al. (2012) \\
\hline $30.7-30.9$ & $31.10-31.12$ & $1-2.1$ & $0.22-0.31$ & South Sumatera waters & Isnaini, et al. (2014a) \\
\hline
\end{tabular}

tration firstly and then decrease very fast due to be used by $C$. polykrikoides forblooming. Furthermore, Muawanah et al. (2013) stated that during C. polykrikoides blooming, DIN concencentration was ranged $0,016-1,219 \mathrm{mg} \cdot \mathrm{L}^{-1}$ and ortho-phosphate concentration was ranged $0,001-0,150$ mg. $\mathrm{L}^{-1}$. The other environmental parameters were $30-32 \mathrm{psu}$; 27,9-29, $8^{0} \mathrm{C}$; 4,30-5,64 mg.L ${ }^{1}$; and $\mathrm{pH} 7,45-7,99$ for salinity, temperatur, dissolved xygen, and $\mathrm{pH}$ respectively.The study of Widiarti (2000) showed thatSkeletonema had positive correlation with phosphate, while Pyrodinium was more affected by salinity and high nitrat concentration that were usually found near the mangrove area.

Different phenomena of algae blooming from previous studies suggested that the causes of algae bloom were unclear and might be related to many environment factors.

\section{CONCLUSION}

The study found 13 species that were identified as Harmful Algal (Chaetoceros, Coscinodiscus, Nitzschia, Skeletonema, Thalassiosira, Alexandrium, Ceratium, Dinophysis, Noctiluca, Protoperidinium, Prorocentrum, Anabaena and Oscillatoria), with 7 of them contain toxin (Nitzschia, Alexandrium, Dinophysis, Protoperidinium Prorocentrum, Anabaena and Oscillatoria) in Banyuasin water. Monitoring result showed that the highest number of potential HABs were in June and the highest abundance of algae was in August.

\section{ACKNOWLEDGEMENT}

The authors would like to give a grateful to Directorate General of Higher Education (DIKTI) for the financial support. We also deliver thanks to Heron Surbakti, M.Si and Isnaini, M.Si for their full support to this research. Addition- ally, we wish to thank T. Zia Ulqodry, Ph.D, and Suhartono, M.Si for helping manuscript correction.

\section{REFERENCES}

American Public Health Association \& Federation, W. E. (2005). Standard methods for the examination of water and wastewater. American Public Health Association (APHA): Washington, DC, USA.

Anderson, D. M., Gilbert, P. M. \& Burkholder, J. M. (2002). Harmful Algal Blooms and Eutrophication: Nutrient Sources, Composition and Consequences. Estuaries, 25(4),704-726.

Anderson, D. M., Regiera, B., Pitcher, G. C. \& Enevoldsen, H. O. (2010). History and Science Impact Harmful Algal Blooms. Oceanography, 23(3), 72-85.

Aquino, J., Flores, B., \& Naguit, M. (2010). Harmful algal bloom occurrence in Murcielagos Bay amidst climate change. E-International Scientific Research Journal, 2(4), 358-365.

Aryawati, R., Surbakti, H. \& Ulqodry, T. Z. (2005). Hubungan Kondisi Oseanografi dengan Kelimpahan Phytoplankton di Perairan Banyuasin. Pemanfaatan dan Pengelolaan Perairan Umum secara Terpadu bagi Generasi Sekarang dan Mendatang. 2004 Juli 27-29. Palembang: BRPPU.

Danielsdottir, M. G., Brett, M. T., \& Arhonditsis, G. B. (2007). Phytoplankton food quality control of planktonic food web processes. Hydrobiologia, 589(1), 29-41.

Edler, L., \& Elbrächter, M. (2010). The Utermöhl method for quantitative phytoplankton analysis. 13-20. Microscopic and molecular methods for quantitative phytoplankton analysis. Intergovernmental Oceanographic Commission of UNESCO. IOC Manuals and Guides, 55.

Fathi, A. A., \& Al-Kahtani, M. A. (2009). Water quality and planktonic communities in Al-khadoud spring, Al-Hassa, Saudi Arabia. American Journal of Environmental Sciences, 5(3), 434.

Hallegraeff, G. M. (1995). Harmfull algal blooms: A global overview. In Hallegraeff GM, Anderson DM and Cambella AD, editor. Manual on Harmful Marine Microalgae. Franch: UNESCO. 
pp. 1-22.

Hasani, Q., Adiwilaga, E. M. \& Pratiwi, N. T. M. (2012). The relationship between the harmful algal blooms (habs) phenomenon withnutrients at shrimp farms and fish cage culture sites in pesawaran district Lampung Bay. Makara Journal of Science, 16(3), 183-191.

Haumahu, S. (2004). Distribusi spasial phytoplankton di Teluk Ambon bagian dalam. Ichtyos, 3(2), 9198.

Haumahu, S. (2005). Distribusi spasial phytoplanktondi perairan Teluk Haria Saparua, Maluku tengah. Ilmu Kelautan, 10(3), $126-134$.

Ismunarti, D. H. (2013). Analisis komponen utama pada hubungan distribusi spasial komunitas fitoplankton dan faktor lingkungan. Ilmu Kelautan, 18(1), 14-19.

Isnaini. (2012). Struktur komunitas phytoplankton di perairan Muara Sungai Banyuasin Sumatera Selatan. Maspari Journal, 4(1), 58-68.

Isnaini. (2014a). Komposisi dan Kelimpahan Phytoplankton di Perairan Sekitar Pulau Maspari, Ogan Komering Ilir. Maspari Journal, 6(1), 3945.

Isnaini. (2014b). Distribusi spasial phytoplankton di perairan Selat Bangka. Simposium Nasional I Kelautan dan Perikanan. FIKP. Universitas Hasanuddin. Makassar.

Lagus, A., Suomela, J., Weithoff, G., Heikkilä, K., Helminen, H., \& Sipura, J. (2004). Species-specific differences in phytoplankton responses to $\mathrm{N}$ and $\mathrm{P}$ enrichments and the $\mathrm{N}$ : $\mathrm{P}$ ratio in the Archipelago Sea, northern Baltic Sea. Journal of Plankton Research, 26(7), 779-798.

Makmur, M. (2008). Pengaruh Upwelling terhadap Ledakan Alga (Blooming Algae) di Lingkungan Perairan Laut. Prosiding Seminar Nasional Teknologi Pengolahan Limbah VI Pusat Teknologi Limbah Radioaktif BATAN. Pusat Penelitian Ilmu Pengetahuan dan Teknologi-RISTEK.

Muawanah, Widiatmoko, W. \& Haryono, T. (2013). Red Tide di Teluk Lampung [Internet]. Tersedia pada: http://bbpbl.djpb.kkp.go.id/index.php/ component/content/article/74-red-tide.html. Diunduh pada 5 Januari 2013.

Widiarti, R., \& Wardhana, W. (2012). Sebaran Spasial Spesies Penyebab Harmful Algal Bloom (HAB) di Lokasi Budidaya Kerang Hijau (Perna viridis) Kamal Muara, Jakarta Utara, Pada Bulan Mei 2011. Jurnal Akuatika, 3(1), 28-39.

Pednekar, S. M., Prabhu Matondkar, S. G., \& Kerkar, V. (2012). Spatiotemporal distribution of harmful algal flora in the tropical estuarine complex of Goa, India. The Scientific World Journal,12.

Praseno, D. P \& Sugestiningsih. (2000). Retaid di Perai- ran Indonesia. Jakarta: P3O-LIPI.

Prianto, E., Husnah, Makri, \& Wijaya, D. (2010). Distribusi Longitudinal Ikan Berdasarkan SumberPolutan di Sungai Musi. Prosiding Seminar Nasional Limnologi V. pp. 190-204.

Pusat Penelitian Oseanografi Lembaga Ilmu Pengetahuan Indonesia (P2O-LIPI). (2015). Tersedia pada: Ini hasil uji Lab LIPI terkait kasus jutaan ikan yang mati di Pantai Ancol-detiknews, http://m.detik.com/news/berita/3085497/. Diunduh pada 2 Desember 2015.

Rokhim, K., Arisandi, A. \& Abida, I. W. (2009). Analisis kelimpahan fitoplankton dan ketersediaan nutrien $\left(\mathrm{NO}_{3}\right.$ dan $\left.\mathrm{PO}_{4}\right)$ di perairan Kecamatan Kwanyar Kabupaten Bangkalan. Jurnal Kelautan. 2(2), 7-16.

Sellner, K. G., Doucette, G. J., \& Kirkpatrick, G. J. (2003). Harmful algal blooms: causes, impacts and detection. Journal of Industrial Microbiology and Biotechnology, 30(7), 383-406.

Siagian, R. S. (2006). Distribusi dan struktur komunitas phytoplankton di Perairan Teluk Jakarta dan kaitannya dengan red tide. Skripsi. Bogor: Institut Pertanian Bogor.

Sidabutar, T. (2006). Fenomena red tide yang dapat mengakibatkan kerugian pada sektor perikanan. Prosiding Seminar Nasional Tahunan III Hasil Penelitian Perikanan dan Kelautan. Jurusan Perikanan dan Kelautan Fakultas Pertanian, Universitas Gadjah Mada. pp. 114-126.

Surbakti, H., Aryawati, R. \& Isnaini. (2011). Pemodelan Sebaran Nutrien dan Produktivitas Primer untuk Identifikasi Daerah Penangkapan Ikan di Perairan Selat Bangka. Laporan Penelitian. Palembang: Universitas Sriwijaya

Thoha, H. (2003). Pengaruh musim terhadap plankton di perairan Riau Kepulauan dan sekitarnya. Makara Seri Sains, 7(2), 59-70.

Thoha, H \& Aryawati, R. (2014). Kondisi Fitoplankton di Perairan Teluk Jakarta. Seminar Nasional MIPA: Peran MIPA dalam pengelolaan sumberdaya alam untuk kemakmuran bangsa. pp. 516-526.

Tomas, C. R. (1997). Identifying Marine Phytoplankton. California: Academic Press.

Widiarti, R. (2000). Pola Suksesi Organisme Penyebab Red Tide Pyrodinium bahamense Plate di Teluk Hurun Lampung Selatan. Thesis. Bogor: Institut Pertanian Bogor.

Yamaji, I. (1966). Illustration of the Marine Plankton of Japan. Hoikusho, Osaka, Japan. pp. 369.

Yuliana. (2012). Implikasi perubahan ketersediaan nutrien terhadap perkembangan pesat (blooming) phytoplankton di perairan Teluk Jakarta. Thesis. Bogor: Institut Pertanian Bogor. 